\title{
Protein Farnesyltransferase Subunit Beta
}

National Cancer Institute

\section{Source}

National Cancer Institute. Protein Farnesyltransferase Subunit Beta. NCI Thesaurus. Code C38604.

Protein farnesyltransferase subunit beta ( $437 \mathrm{aa}, \sim 49 \mathrm{kDa}$ ) is encoded by the human FNTB gene. This protein plays a role in protein farnesylation. 